\title{
LITERASI EKONOMI SYARIAH DAN TEMAN SEBAYA TERHADAP MINAT MENABUNG DI PERBANKAN SYARIAH
}

\author{
Noni Rozaini ${ }^{1)}$, Rizki Husnul Amelia ${ }^{1}$, Ina Namora Putri Siregar ${ }^{2}$, Mica Siar Meiriza ${ }^{1)}$ \\ ${ }^{1)}$ Fakultas Ekonomi, Universitas Negeri Medan \\ 2) Fakultas Ekonomi, Universitas Prima Indonesia \\ *Penulis Korespondensi: nonirozaini@gmail.com, rizkihamelia88@gmail.com, inanamoraputri@gmail.com, \\ althamira@yahoo.com
}

\begin{abstract}
This study aims to determine how much the influence of sharia economic literacy and peers on student savings interest in Islamic banking (study on students of the 2014 batch of Economic Education Study Program at the State University of Medan. The population in this study were all students of 2014 Economic Education Study Program totaling 126 students with 96 students as research samples.The sampling technique used is simple random sampling. Data collection techniques are carried out by means of tests and questionnaires. Test the validity of the questionnaire using the Pearson product moment formula, and its reliability is calculated using Cronbach Alpha. The research data analysis technique is multiple linear regression to test the research hypothesis using $t$ test and $F$ test. The results of multiple regression analysis obtained equation $Y=31,058-0,020 X 1+0,320 X 2+e$. Furthermore, the coefficient of determination (R2) is 0.362 which means that it is equal to $36.2 \%$, the variables $X 1$ and $X 2$ can explain the interest in saving students $(Y)$ and the scales of $63.8 \%$ are explained by other variables not examined in this study. Based on the t test, it was found that each variable XI did not have a positive and significant effect on students' savings interest $(Y)$ in Islamic banking with a tcount <ttable $(0.675<1.666)$ and there was a positive and significant influence between $X 2$ variables on student savings $(Y)$ in Islamic banking with a value of $t>t$ table (7.259> 1.666). While the $F$ test found that there is a positive and significant influence between Islamic economic literacy (X1) and peers (X2) on the interest in saving students $(Y)$ in Islamic banking with a value of Fcount $>$ Ftable (26.739> 3.09) and significance value $(0,000<0,05)$.
\end{abstract}

Keywords: Sharia Economic Literacy, Peer Friend, Savings Interest.

Article Information:

Received Date: 18 Februari 2022

Revised Date: 24 Februari 2022

Accepted Date: 5 Maret 2022 


\section{PENDAHULUAN}

Seiring dengan tumbuh dan berkembangnya perbankan syariah di Indonesia yang kian dinamis, masyarakat Indonesia terutama masyarakat muslim dihadapkan pada berbagai permasalahan ekonomi. Tidak hanya pada tataran praktek operasional, perbankan syariah juga mengalami peningkatan dalam kajiankajian akademis di berbagai perguruan tinggi. Maraknya riset dan kajian ilmiah di bidang ini merupakan apresiasi dan wujud dukungan penuh dari masyarakat akan pentingnya perbankan syariah di Indonesia, di tengah keraguan akan sistem konvensional yang lekat dengan sistem ribawi dan jauh dari memberikan rasa keadilan dan pemerataan ekonomi.

Perkembangan bank syariah selama hampir 28 (dua puluh delapan) tahun di Indonesia, sementara itu perkembangan industri perbankan syariah sampai dengan bulan Desember 2017 yaitu, industri perbankan syariah telah mempunyai jaringan sebanyak 13 Bank Umum Syariah (BUS), 21 Unit Usaha Syariah (UUS), dan 167 Bank Pembiayaan Rakyat Syariah (BPRS), dengan total jaringan kantor mencapai 2.610 kantor yang tersebar di hampir seluruh penjuru nusantara. Dari tabel di bawah ini terlihat naik turunnya 6 tahun terakhir jumlah masing masing bank dan kantor dari setiap Bank Umum Syariah (BUM), Unit Usaha Syariah (UUS), dan Bank Pembiayaan Rakyat Syariah (BPRS).

\section{Tabel. 1. Perkembangan Bank Syariah di} Indonesia

\begin{tabular}{|c|c|c|c|c|c|}
\hline Bank & 2012 & 2013 & 2014 & 2015 & 2016 \\
\hline \multicolumn{6}{|l|}{ Bank Umum Syariah (BUS) } \\
\hline - Jumlah Bank & 11 & 11 & 12 & 12 & 13 \\
\hline - Jumlah Kantor & 1.745 & 1.998 & 2.163 & 1.990 & 1.869 \\
\hline \multicolumn{6}{|l|}{ Unit Usaha Syariah (UUS) } \\
\hline $\begin{array}{l}\text { Jumlah Bank } \\
\text { Umum yang } \\
\text { memiliki UUS }\end{array}$ & 24 & 23 & 22 & 22 & 21 \\
\hline - Jumlah Kantor & 517 & 590 & 320 & 311 & 332 \\
\hline \multicolumn{6}{|l|}{$\begin{array}{l}\text { Bank Pembiayaan Rakyat } \\
\text { Syariah (BPRS) }\end{array}$} \\
\hline - Jumlah Bank & 158 & 163 & 163 & 163 & 166 \\
\hline - Jumlah Kantor & 401 & 402 & 439 & 446 & 453 \\
\hline Jumlah & 2.663 & 2.990 & 2.922 & 2.747 & 2.654 \\
\hline *) sampai Desember 2017 & & & & & \\
\hline
\end{tabular}

Sumber : Statistik Perbankan Syariah 2017

Kegiatan mengatur keuangan untuk seorang mahasiswa pada umumnya adalah mengatur uang saku pemberian dari orangtua. Besar kecilnya uang saku mahasiswa tidak dapat menjadi faktor penentu baik buruknya pengelolahan keuangan. Dari uang saku inilah yang selanjutnya mahasiswa gunakan dalam memenuhi kebutuhan mereka untuk selanjutnya mereka alokasikan ke pengeluaran konsumsi mereka baik konsumsi rutin maupun tidak rutin.

Berdasarkan hasil observasi yang dilakukan penulis, dari 126 mahasiswa prodi pendidikan ekonomi angkatan 2014 dapat disimpulkan bahwa kurangnya minat mahasiswa dalam menggunakan jasa perbankan syariah didasari beberapa hal seperti, 1) merasa malas dan merasa tidak peraktis jika harus membuka rekening baru dan juga menganggap bank konvensional dan bank syariah hanya berbeda istilah saja, 2) masih meragukan praktek bank syariah apakah sudah benar sesuai dengan syariah islam, 3) pengaruh teman sebaya yang memiliki atau tidak memiliki rekening bank syariah. Tetapi dari berbagai macam pernyataan mahasiswa yang tidak minat dalam membuka rekening bank syariah ternyata ada mahasiswa yang telah memiliki rekening bank syariah dan ada pula yang ingin membuka rekening baru bank syariah walaupun telah di fasilitasi pihak kampus dengan memiliki rekening bank konvensional.

Remaja merupakan generasi bangsa yang memiliki peran besar dalam perubahan perekonomian salah satunya melalui kebiasaan menabung. Terlebih jika semangat tersebut diiringi dengan pengetahuan yang telah didapatkan pada pendidikan formal dan diomplementasikan melalui tindakan. Karena remaja lebih banyak berada di luar rumah besama dengan teman-teman sebaya sebagai kelompok, maka dapatlah dimengerti bahwa pèngaruh teman-teman sebaya pada sikap, pembicaraan, minat, penampilan dan perilaku têtkadang lebih besar dari pada pengaruh keluarga.

Menabung memiliki manfaat yang sangat bęsar baik untuk jangka pendek ataupun jangka pasifang seseorang. Halnya menabung bagi mahasiswa, selain untuk membiasakan diri dalam mengendalikan uang yang dimiliki dapat juga sebagai jaga-jaga untuk waktu yang akan datang. Bahkan para mahasiswa yang belajar tentang perbankan syariah sendiri belum tentu 
berminat untuk menabung di perbankan syariah dan telah memiliki rekening perbankan syariah. Oleh karena itu, diharapkan semakin tinggi pemahaman nasabah terhadap perbankan syariah dapat meningkatkan minat menabung dan kepemilikan rekening perbankan syariah. Dari uraian diatas penulis tertarik untuk meneliti tentang pengaruh iterasi ekonomi syariah dan Teman sebaya terhadap minat menabung di perbankan syariah.

\section{TINJAUAN TEORITIS}

\section{Literasi Ekonomi Syariah}

Literasi ekonomi syariah merupakan kemampuan untuk menggunakan konsep dasar ekonomi dan cara berpikir kritis dalam pembuatan keputusan ekonomi yang diilhami oleh nilai-nilai islam. Literasi ekonomi syariah dapat membuat seseorang menunjukkan jati dirinya dalam mengelola sumber daya ekonomi untuk mencapai kesejahteraan dengan cara mengaplikasikan konsep ekonomi syariah tersebut.

Dengan demikian pergaulan teman sebaya dapat mempengaruhi perilaku. Pengaruh tersebutlah yang telah disebutkan beberapa ahli di atas. Dari dampak positif dan negatif pengaruh teman sebaya di atas maka dengan demikian pengaruh teman sebaya yang baik diperlukan untuk perkembangan sosio-emosional yang normal, anak-anak yang ditolak oleh teman sebaya atau menjadi korban temannya maka dia akan merasa kesepian dan beresiko terlibat dengan sejumlah masalah termasuk penyimpangan dan putus sekolah.

\section{Minat menabung di Perbankan Syariah}

Slameto (2010 : 180) berpendapat bahwa "Minat adalah suatu rasa lebih suka dan rasa ketertarikan pada suatu hal atau aktivitas, tanpa ada yang menyuruh.

Menurut Syafi'i, (2001:153) menyatakan:

Menabung adalah tindakan yang dianjurkan oleh islam, karena dengan menabung berarti seseorang muslim mempersiapkan diri untuk pelaksanaan perencanaan masa yang akan datang sekaligus untuk menghadapi hal-hal yang tidak diinginkan.

Menurut Oryza (2017:13) menyatakan "Menabung merupakan salah satu aktivitas yang dianjurkan oleh ajaran agama Islam". Menabung juga dapat mencegah manusia dari sikap boros dan berlebihan.

Menurut Vivi dan Irwan (2005:7) "Minat menabung adalah kekuatan yang mendorong individu untuk memberikan perhatiannya terhadap kegiatan menyimpan uang di bank yang dilakukan secara sadar, tidak terpaksa dan dengan perasaan senang".

Menurut Beni (2017:16) minat terjadi karena adanya pengaruh dari berbagai faktor eksternal dan juga adanya faktor internal :

1) Faktor Internal

Faktor internal adalah sesuatu yang membuat siswa berminat yang berasal dari dalam diri. Faktor internal, seperti pemusatan perhatian, keingintahuan, motivasi, dan kebutuhan.

2) Faktor Eksternal

Faktor eksternal adalah sesuatu yang membuat siswa berminat yang berasal dari luar diri individu. Faktor eksternal, seperti dorongan dari orang tua, dorongan dari guru, tersedianya prasarana dan sarana atau fasilitas, dan keadaan lingkungan.

\section{METODE PENELITIAN}

Penelitian ini dilakukan di Fakultas Ekonomi Universitas Negeri Medan yang beralamat di Jalan Willem Iskandar Psr. V Medan 20221. Penelitian ini dilaksanakan pada semester Genap tahun ajaran 2017/2018.

Populasi dalam penelitian ini adalah seluruh mahasiswa program studi pendidikan ekonomi angkatan 2014 yaitu sebanyak 126 mahasiswa yang tersebar dalam 4 kelas yaitu reguler A, reguler B, reguler C, dan Ekstensi. Sampel penelitian ini menggunakan rumus Taro Yamame atau Slovin dengan hasil perhitungan sampel menjadi 96 mahasiswa. Sebelum dilakukan penelitian terlebih dahulu dilakukan uji instrumen untuk mengetahui validitas dan reabilitas angket penelitian yang digunakan, maka perlu melakukan uji coba instrumen penelitian. Adapun uji coba instrumen adalah Uji Validitas Uji Reliabilitas Uji Normalitas Uji Linieritas Uji Multikolinearitas Analisis Regresi Linear Berganda

\section{HASIL DAN PEMBAHASAN \\ 1. Uji Instrumen Penelitian \\ a. Uji Validitas}

Dari hasil uji validitas menggunakan SPSS 20, mendapatkan 20 butir instrumen angket teman sebaya $\left(\mathrm{X}_{2}\right)$ yang valid. 20 butir instrumen angket minat menabung (Y) disimpulkan bahwa 20 soal angket yang di uji coba, semua item pertanyaan dalam angket dinyatakan valid 
setelah data di olah semua item pertanyaan memiliki nilai $r_{\text {hitung }}>r_{\text {tabel }}$.

\section{b. Uji Reliabilitas}

Berdasarkan uji reliabilitas dengan menggunakan rumus Cronbach's Alpha dari diperoleh hasil variabel teman sebaya $\left(\mathrm{X}_{2}\right)$ sebesar 0,906 dari 20 butir pertanyaan yang valid. Nilai tersebut lebih besar dari nilai $r_{\text {tabel }}$ dengan taraf signifikasi sebesar 5\% yaitu 0,361. Angka ini menunjukkan bahwa angket terbukti reliabel sebab $r_{\text {hitung }}>r_{\text {tabel }}(0,906>0,361)$. Untuk variabel minat menabung $(\mathrm{Y})$ sebesar 0,886 dari 20 butir pertanyaan yang valid. Nilai tersebut lebih besar dari nilai $r_{\text {tabel }}$ dengan taraf signifikasi sebesar 5\% yaitu 0,361 . Angka ini menunjukkan bahwa angket terbukti reliabel sebab $r_{\text {hitung }}>r_{\text {tabel }}$ $(0,886>0,361)$.

\section{Uji Prasyarat Analisis Data \\ a. Uji Normalitas}

Dari hasil uji normalitas menggunakan SPSS didapat nilai signifikansi sebesar 0,418. Hal ini menunjukkan bahwa data yang digunakan memiliki distribusi normal karena nilai kolmogorov smirnov memiliki tingkat sig $=$ $0,418>0,05$.

\section{b. Uji Linieritas}

Berdasarkan hasil perhitungan yang diperoleh dari SPSS 20 dapat diketahui bahwa literasi ekonomi syariah $\left(\mathrm{X}_{1}\right)$ memiliki nilai signifikansi pada Deviation from Linearity sebesar $0,328>0,05$. Dari data tersebut dapat disimpulkan bahwa literasi ekonomi syariah $\left(\mathrm{X}_{1}\right)$ mempunyai hubungan yang linear terhadap minat menabung (Y). Begitu juga teman sebaya $\left(\mathrm{X}_{2}\right)$ memiliki nilai signifikansi pada Deviation from Linearity sebesar 0,358>0,05. Dari data tersebut dapat disimpulkan bahwa kelompok teman sebaya $\left(\mathrm{X}_{2}\right)$ mempunyai hubungan yang linear terhadap minat menabung $(\mathrm{Y})$.

\section{c. Uji Multikolinearitas}

Berdasarkan hasil SPSS 20 didapat bahwa nilai tolerance pada kedua variabel bebas yaitu literasi ekonomi syariah dan teman sebaya sebesar 0,999 dimana nilai tersebut >0,10. Selanjutnya nilai VIF pada variabel bebas X1 dan X2 yaitu 1,001 dimana nilai tersebut $<10$. Dengan demikian dapat disimpulkan bahwa tidak terjadi multikolinearitas antar variabel bebas dalam penelitian ini.

\section{Analisis Regresi Linear Berganda}

Dari hasil perhitungan program SPSS 20 pada tabel diperoleh koefisien regresi linear berganda untuk $\mathrm{X} 1=-0,020, \mathrm{X} 2=0,320$, sedangkan konstnta regresi adalah 31,058, sehingga persamaan regresi linear berganda adalah:

$$
Y=31,058-0,020 X_{1}+0,320 X_{2}+e
$$

\section{Uji Hipotesis}

\section{a. Uji Parsial (Uji t)}

Dari hasil SPSS dapat disimpulkan bahwa $\mathrm{t}_{\text {hitung }}<\mathrm{t}_{\text {tabel }}$ atau $0,675<1,666$. Karena nilai $\mathrm{t}_{\text {hitung }}<\mathrm{t}_{\text {tabel }}$ dan nilai sig 0,502>0,05 yang berarti hipotesis ditolak. Artinya, variabel literasi ekonomi syariah tidak berpengaruh terhadap minat menabung di perbankan syariah pada mahasiswa Program Studi Pendidikan Ekonomi angkatan 2014 di Fakultas Ekonomi Universitas Negeri Medan.

Variabel literasi ekonomi syariah memiliki

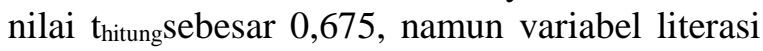
ekonomi syariah pada penelitian ini berpengaruh negatif dengan nilai yaitu 0,020 artinya mahasiswa yang memiliki pemahaman ekonomi syariah lebih terhadap perbankan syariah justru menurunkan keinginan mahasiswa untuk menabung di perbankan syariah sebesar 0,020 kali dibanding dengan mahasiswa yang memiliki pemahaman ekonomi syariah yang kurang baik terhadap perbankan syariah. Variabel literasi ekonomi syariah ini sejalan dengan penelitian Noorhidayah (2016:27-28) yang hasil penelitiannya variabel pengetahuan tidak berpengaruh dan bertanda negatif terhadap minat menabung responden terhadap perbankan syariah.

Seluruh mahasiswa Universitas Negeri Medan khususnya mahasiswa prodi Pendidikan Ekonomi difasilitasi dari pihak kampus dengan memiliki KTM (Kartu tanda Mahasiswa) yang berasal dari Bank BNI, dimana Bank BNI tersebut termasuk dalam kategori bank konvensional. Bank BNI juga telah memiliki sistem syariah, hanya saja bank BNI yang menggunakan sistem syariah belum mempromosikan kepada mahasiswa Universitas Negeri Medan. Jadi mahasiswa belum begitu familiar mendengar kata bank syariah, terlebih lagi mahasiswa yang tidak ada mata kuliah atau pengetahuan diluar mata kuliah.

Jika dilihat dari faktor yang mempengaruhi minat menabung yang telah dijelaskan di atas, dapat disimpulkan mengapa literasi ekonomi 
syariah tidak berpengaruh terhadap minat menabung. Karena minat menabung terjadi apabila seorang mahasiswa mampu untuk merencanakan dan mengatur kondisi keuangan yang bersumber dari orang tua mereka, yang akhirnya mahasiswa tidak termotivasi untuk menabung di bank syariah dengan kondisi keuangan yang terbatas tersebut. Sehingga ilmu yang didapatkan pada mata kuliah ekonomi syariah tidak dapat diaplikasikan dalam kehidupan nyata. Maka yang terjadi tingkat literasi ekonomi syariah yang dimiliki tidak berpengaruh terhadap perilaku menabung mahasiswa.

Serta masalah pada bank syariah yang belum memiliki modal yang memadai, sehingga kurangnya modal akan menghambat bank-bank syariah dalam membuka kantor cabang di daerah-daerah, mengembangkan infrastruktur, dan pengembangan segmen layanan. Jauh atau dekatnya lokasi bank syariah tidak akan menghambat minat seorang calon nasabah untuk tetap jadi nasabah dalam menggunakan bank syariah apabila ia telah mengetahui kelebihan dari bank syariah tersebut, tetapi jika seorang nasabah mengerti dan memahami tentang produk dan sistem perbankan syariah mau sejauh apapun kantor bank syariah maka ia akan tetap menggunakan perbankan syariah. Maka dari itu pemahaman dan kesadaran calon nasabah yang masih rendah ke bank syariah yang selama ini harus lebih ditingkatkan lagi.

Dari hasil SPSS dapat disimpulkan bahwa $t_{\text {hitung }}>t_{\text {tabel }}$ dan nilai sig 7,259>1,666 yang berarti hipotesis dapat diterima. Artinya, variabel teman sebaya berpengaruh positif dan signifikan terhadap minat menabung pada mahasiswa Program Studi Pendidikan Ekonomi angkatan 2014 di Fakultas Ekonomi Universitas Negeri Medan.

Variabel teman sebaya memiliki nilai $\mathrm{t}_{\text {hitung }}$ sebesar 7,259 dan variabel teman sebaya pada penelitian ini berpengaruh positif yaitu dengan nilai 0,320 . Hal ini menunjukkan bahwa mahasiswa yang memiliki teman sebaya yang baik akan meningkatkan peluang mahasiswa untuk menabung di bank syariah sebesar 0,320 kali dibandingkan dengan mahasiswa yang memiliki teman sebaya yang buruk. Dapat disimpulkan perilaku atau kebiasaan seseorang dapat dilihat dari teman sebayanya. Jika teman sebayanya memiliki kebiasaan positif seperti gemar menabung, maka orang tersebut akan memiliki kebiasaan yang sama yaitu akan gemar menabung, demikian juga sebaliknya.

Perilaku teman sebaya dapat dikontrol dengan cara memberikan pengarahan kepada siswa dengan memerhatikan batasan-batasan dalam berteman, jangan sampai berteman dengan teman yang memiliki kebiasaan konsumtif yang nantinya akan berdampak pada sulitnya meningkatkan kebiasaan menabung. Semakin besar pengaruh teman sebaya yang baik, maka semakin tinggi minat menabung mahasiswa. Sebaliknya semakin kecil pengaruh teman sebaya yang tidak baik, maka semakin rendah pula minat menabung di perbankan syariahpada mahasiswa Program Studi Pendidikan Ekonomi angkatan 2014 di Fakultas Ekonomi Universitas Negeri Medan.

\section{b. Uji Simultan (Uji f)}

Dari hasil perhitungan diperoleh nilai $F_{\text {hitung }}>F_{\text {tabel }}$ atau 26,739>3,09 dan nilai sig sebesar $0,000<0,05$ sehingga dapat disimpulkan bahwa ada pengaruh yang positif dan signifikan antara literasi ekonomi syariah dan teman sebaya terhadap minat menabung di perbankan syariah pada mahasiswa Program Studi Pendidikan Ekonomi angkatan 2014 di Fakultas Ekonomi Universitas Negeri Medan.

\section{c. Koefisien Determinasi $\left(\mathbf{R}^{2}\right)$}

Berdasarkan hasil pengolahan menunjukkan bahwa koefisien Dari tabel 4.16 nilai koefisien dapat dilihat, diperoleh determinasi $\left(\mathrm{R}^{2}\right)$ 0,362 $(36,2 \%)$ berarti bahwa $36,2 \%$ perubahan pada minat menabung yang dipengaruhi oleh literasi ekonomi syariah dan teman sebaya, sedangkan $63,8 \%$ sisanya dipengaruhi oleh faktor lain yang diteliti.

\section{KESIMPULAN DAN SARAN}

Berdasarkan Berdasarkan data yang diperoleh dari dasil analisis pengujian dan pembahasan terhadap hasil penelitian yang telah dikumpulkan mengenai Literasi Ekonomi Syariah dan Teman Sebaya terhadap Minat Menabung Mahasiswa di Perbankan Syariah pada Mahasiswa Program Studi Pendidikan Ekonomi Angkatan 2014 di Fakultas Ekonomi Universitas Negeri Medan, maka dapat ditarik kesimpulan :

Berdasarkan hasil analisis linear berganda maka diperoleh persamaan $\mathrm{Y}=31,058$ - 0,020 $X_{1}+0,320 X_{2}+$ e. Dari persamaan tersebut maka terdapat nilai konstanta (a) sebesar 31,058, artinya jika variabel X1 dan X2 sebesar nol, maka minat menabung mahasiswa (Y) adalah sebesar 31,058. Selanjutnya untuk 
nilai koefisien regresi variabel X1 (b1) sebesar 0,020 . Artinya jika variabel X1 mengalami kenaikan sebesar satuan dan variabel independen lainnya bernilai tetap, maka minat menabung mahasiswa (Y) mengalami kenaikan sebesar $0,020 \%$. Sementara itu, nilai koefisien regresi variabel X2 (b2) terdapat nilai sebesar 0,320. Artinya jika variabel X2 mengalami kenaikan sebesar satuan dan variabel independen lainnya bernilai tetap, minat menabung mahasiswa $(\mathrm{Y})$ mengalami kenaikan sebesar $0,320 \%$.

Tidak terdapat pengaruh positif dan signifikan antara literasi ekonomi syariah (X1) terhadap minat menabung mahasiswa di perbankan syariah (studi pada mahasiswa Program Studi Pendidikan Ekonomi Angkatan 2014 Universitas Negeri Medan). Hal tersebut dapat dilihat dalam uji $\mathrm{t}$ dimana nilai $\mathrm{t}_{\text {hitung }}>\mathrm{t}_{\text {tabel }}$ sebesar $0,675<1,666$ dan nilai signifikansi $0,502>0,05$.

Ada pengaruh yang positif dan signifikan antara teman sebaya terhadap minat menabung mahasiswa di perbankan syariah (studi pada mahasiswa Program Studi Pendidikan Ekonomi Angkatan 2014 Universitas Negeri Medan). Hal tersebut dapat dilihat dalam uji $\mathrm{t}$ dimana $\mathrm{t}_{\text {hitung }}>\mathrm{t}_{\text {tabel }}$ sebesar $7,259>1,666$ dengan nilai signifikansi $0,000<0,05$.

Ada pengaruh yang positif dan signifikan antara literasi ekonomi syariah dan teman sebaya terhadap minat menabung mahasiswa di perbankan syariah (studi pada mahasiswa Program Studi Pendidikan Ekonomi Angkatan 2014 Universitas Negeri Medan), dimana $F_{\text {hitung }}>F_{\text {tabel }}(26,739>3,12)$ dengan nilai signifikan sebesar $0,000<0,05$.

Literasi ekonomi syariah (X1) dan teman sebaya (X2) memberikan sumbangan pengaruh atau koefisien determinasi $\left(\mathrm{R}^{2}\right)$ sebesar $0,362(36,2 \%)$ berarti bahwa $36,2 \%$ perubahan pada minat menabung yang dipengaruhi oleh literasi ekonomi syariah dan teman sebaya, sedangkan $63,8 \%$ sisanya dipengaruhi oleh faktor lain yang tidak diteliti.

\section{REFERENSI}

Andespa, Roni. (Januari-Juni 2017). FaktorFaktor Yang Mempengaruhi Minat Nasabah Dalam Menabung Di Bank Syariah. Journal Universitas Islam Negeri Imam Bonjol Padang. Volume 2, Nomor 1. Diakses 28 januari 2018.
Arikunto, Suharsimi. 2010. Prosedur Penelitian suatu Pendekatan Praktik. Jakarta: PT Rineka Cipta.

Ascarya, Diana Yumanita. 2005. Bank Syariah : Gambaran Umum. Jakarta: Pusat Pendidikan dan Studi Kebanksentralan (PPSK) BI.

Chotimah dan Rohayati. (2015). Pengaruh Pendidikan Keuangan Di Keluarga, Sosial Ekonomi Orang Tua, Pengetahuan Keuangan, Kecerdasan Spiritual, Dan Teman Sebaya Terhadap Manajemen Keuangan Pribadi Mahasiswa S1 Pendidikan Akuntansu Fakultas Ekonomi Universitas Negeri Surabaya. Jurnal Pendidikan Akuntansi. Vol.3, No.2

Ghofur, Abdul. 2017. Pengantar Ekonomi Syariah: Konsep Dasar, Paradigma, Pengembangan Ekonomi Islam. Depok: Rajawali Press.

Muthia Triani. (2017). Analisis Saving

Behaviour Pada Mahasiswa S1 Di Kota

Padang. Skripsi Universitas Andalas.

Rozaini Noni , M. Yusuf Harahap dan M. Nasir Nasution. Interdependensi Variabel Makro Ekonomi terhadap Perkembangan Aset Perbankan Syariah.Volume 17 Number 1 June 2017. Diakses 27 Maret 2018.

Noorhidayah. 2016.Faktor-Faktor Yang Memengaruhi Preferensi Mahasiswa Terhadap Tabungan Syariah (Studi Kasus: Sekolah Tinggi Ekonomi Islam Tazkia). Bogor.Fakultas Ekonomi Dan Manajemen.Institut Pertanian Bogor.

Nurhipnudin. 2015. Analisis Faktor-Faktor yang Mempengaruhi Minat Bertransaksi Mahasiswa Non Muslim Pada Bank Syariah [Skripsi]. Yogyakarta(ID): Fakultas Syariah dan Hukum, Universitas Islam Negeri.

Nuraeni. (2015). Pengaruh Literasi Ekonomi, Kelompok Teman Sebaya Dan Kontrol Diri Terhadap Perilaku Pembelian Impulsif Untuk Produk Fashion Pada Mahasiswa Fakultas Ekonomi Universitas Negeri Yogyakarta.Skripsi Universitas Negeri Yogyakarta.

Oryza Rachim Septiani. 2017. Faktor-Faktor Yang Mempengaruhi Minat Nasabah Menabung di Bank Syariah Studi Manajemen. Skripsi Universitas 
Muhammadiyah Purwokerto. Diakses 1 April 2018.

Peter G Sina. 2012. Literasi Ekonomi. Diakses dari http://ekonomi.kompasiana.com/moneter/ 2012/05/01/literasiekonomi459579.html. 27 Februari 2018.

Menabung Di Bank Syariah, SkripsiFakultas Ekonomi Dan Bisnis Islam Institut Agama Islam Negeri (Iain), Salatiga.

Rozaini, Noni dan Al Barawi, Qomar. 2018. Pengantar Ekonomi Syariah. Medan: Madenatera.

Rozaini, Noni. Persepsi Siswa Tentang Ekonomi Syariah Dan Hubungannya Dengan Minat Mempelajari Ekonomi Syariah.Jurnal Ekonomi. Diakses 27 Maret 2018.

Rusdianto, Hutomo dan Chanafi Ibrahim. Pengaruh Produk Bank SyariahTerhadap Minat Menabung DenganPersepsi Masyarakat Sebagai VariabelModerating Di Pati. Universitas Muria Kudus. Volume 4, Nomor 1, Juni 2016, 43 - 61.Diakses 17 januari 2018.

Umam, Khotibul. 2016. Perbankan Syariah: Dasar-dasar dan Dinamika Perkembangannya di Indonesia. Jakarta: Rajawali Pers.

Vivi Permata Sari Dan Irwan Nuryana K. 2005. Hubungan Kecerdasan Ruhaniah Dengan Minat Menabung Di Bank Syariah.

Naskah Publikasi. Fakultas Psikologi Universitas Islam Indonesia Yogyakarta.

Wahana, Arwansa. (2014). Analisis faktor-faktor yang mempengaruhi perilaku mahasiswa dalam menabung (studi kasus mahasiswa strata satu fakultas ekonomika dan bisnis universitas diponegoro tembalang). Skripsi. Program Sarjana Fakultas Ekonomika dan Bisnis Universitas Diponegoro.

Wulandari dan Hakim. (2015). Pengaruh Love Of Money, Pendidikan Keuangan Di Keluarga, Hasil Belajar Manajemen Keuangan, Dan Teman Sebaya Terhadap Manajemen Keuangan Pribadi Mahasiswa. Jurnal Akuntansi. Vol.3, No.3, Hal.1-6. 